\title{
Dolor abdominal asociado con esplenosis pélvica*
}

\author{
Drs. VALDEMIR JOSÉ ALEGRE SALLES ${ }^{1}$, RENATO MORETTI MARQUES ${ }^{1}$, \\ XENOFONTE PAULO R. MAZZINI ${ }^{1}$, CAROLINA G. MAGALHÃES ${ }^{1}$ \\ 1 Universidad de Taubaté, Departamento de Medicina, São Paulo, Brasil.
}

\section{Abdominal pain associated with pelvic splenosis}

Una mujer de 34 años de edad, fue admitida en el servicio de cirugía; se quejaba de dolor pélvico crónico, infertilidad, dispareunia y estreñimiento. Los estudios de laboratorio mostraron leucocitosis de 14.000 , neutrófilos de $68 \%$, plaquetas de 260 mil y bandas de 1\%; análisis de orina y las pruebas de coagulación fueron normales.Tenía antecedentes de esplenectomía por rotura traumática en accidente de tráfico en su infancia. En la ecografía transvaginal un tumor de 4,5 cm unido a la pared uterina fue

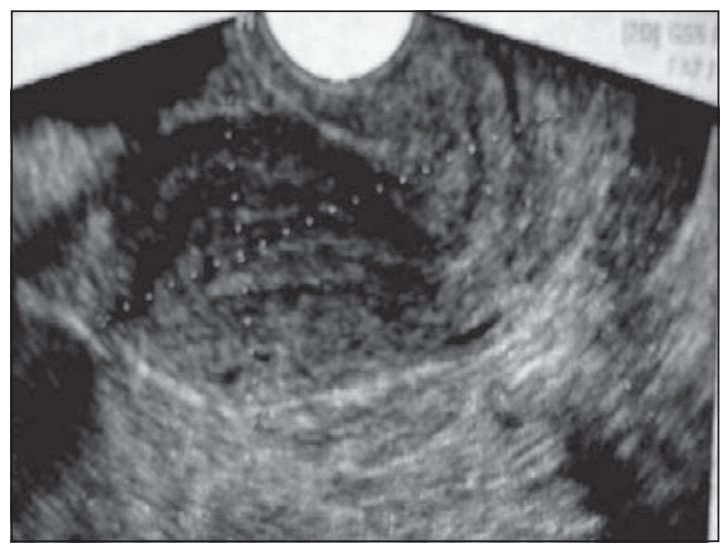

Figura 1. Ecografía transvaginal demuestra un tumor en la pared uterina. demostrado (Figura 1). Una resonancia magnética confirmó la presencia del tumor retrocervical junto al recto (Figura 2). Fue remitida a la unidad de oncología ginecológica y sometida a laparotomía. Una esplenosis pélvica diseminada se confirmó (Figura $3)$. Después de este procedimiento, el dolor abdominal cesó. El estudio histopatológico reveló el tejido esplénico, y el diagnóstico de esplenosis pélvica se confirmó. Esplenosis se define por el trasplante heterotópico del tejido esplénico en el peritoneo,

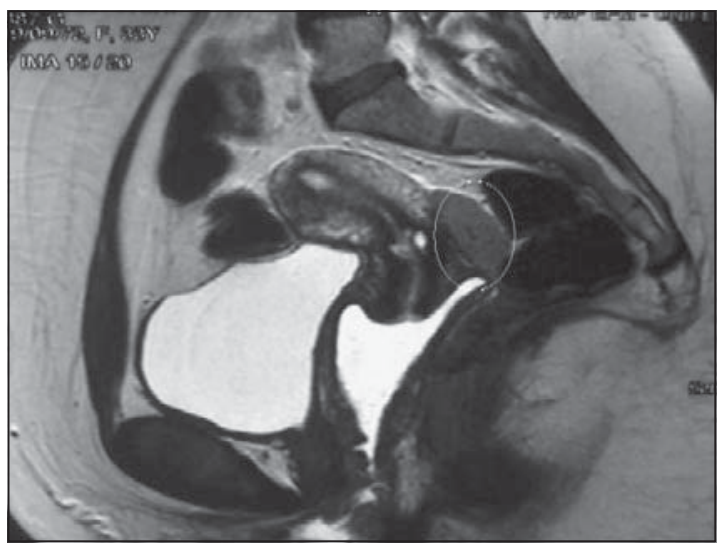

Figura 2. Presencia de tumor retro-cervical identificado por resonancia magnética.

*Recibido el 12 de enero de 2011 y aceptado para publicación el 3 de marzo de 2011.

Correspondencia: Dr. Valdemir José Alegre S.

Endereço: Rua José Bonani, 199. Taubaté, São Paulo, Brasil. CEP: 12031-260

vjasia@gmail.com 


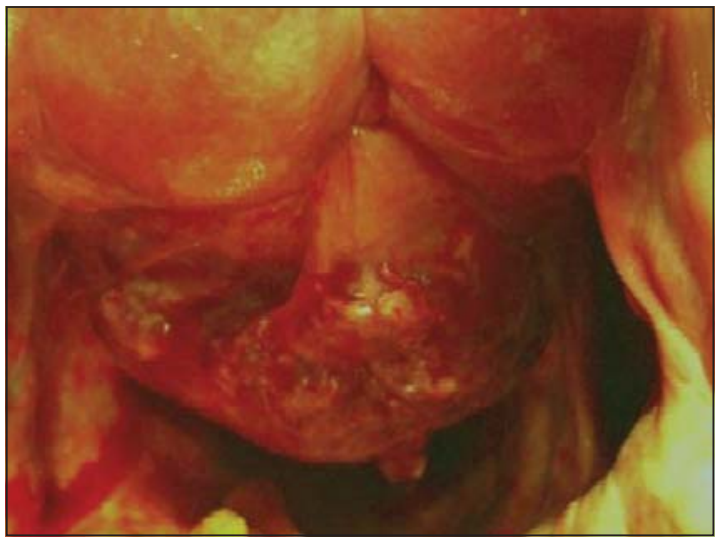

Figura 3. Esplenosis pélvica retro-uterina.

que generalmente sigue a la ruptura traumática del bazo. Los implantes suelen ser múltiples y pueden imitar neoplasias ${ }^{1}$, localizadas en cualquier lugar de la cavidad peritoneal; los diagnósticos diferenciales incluyen la endometriosis, mesotelioma peritoneal, neoplasma renal, linfomas abdominales, adenomas hepáticos e implantes metastáticos. Pueden ocurrir en cualquier parte, pero aparecen con más frecuencia en las superficies serosas del intestino delgado, epiplón, mesenterio, superficie inferior del diafragma y en la pelvis ${ }^{2}$. La ecografía, la tomografía computada y la resonancia magnética puede ayudar en la localización y establecer el tamaño y la estructura de estos implantes y en la determinación de su relación con los órganos adyacentes. En la ecografía, el esplenosis aparece como una masa de tejido hipoecoico y homogénea con un delgado borde de la pared hiperecoica ${ }^{1}$. En la tomografía computada, la esplenosis manifiesta en formas múltiples, a veces como masa homogénea de tejido blando con una densidad levemente más baja que del hígado, especialmente en la fase arterial. En la resonancia magnética, la esplenosis es hipointensa en T1 e hiperintensa en las imágenes $\mathrm{T}^{2}$. El desarrollo de la exploración transvaginal por la sonografia de alta frecuencia ha facilitado el diagnóstico de masas pélvicas relativamente pequeñas, y el avance de técnicas quirúrgicas laparoscópicas puede aumentar la frecuencia de diagnóstico de esplenosis ${ }^{1}$.

\section{Referencias}

1. Garaci FG, Grande M, Villa M, Mancino S, Konda D, Attinà GM, et al. What is a reliable CT scan for diagnosing splenosis under emergency conditions? World J Gastroenterol. 2009;15:3684-6.

2. Imbriaco M, Camera L, Manciura A, Salvatore M. A case of multiple intra-abdominal splenosis with computed tomography and magnetic resonance imaging correlative findings.World J Gastroenterol. 2008;14:1453-5. 